\title{
Türkiye'de İhracat, İthalat ve Ekonomik Büyüme İlişkisi: Zamanla Değişen Nedensellik Analizi
}

(Araştırma Makalesi)

Relationship Between Export, Import and Economic Growth in Turkey: Time Varying Causality Analysis Abstract

Doi: 10.29023/alanyaakademik.687027

\section{Selim DEMEZ}

Dr. Öğr. Üyesi, Hakkari Üniversitesi, İBF, İktisat Bölümü.

selimdemez@hakkari.edu.tr

Orcid No:0000-0001-6885-0499

\section{Oktay KIZILKAYA}

Dr. Ö̈̆r. Üyesi, Hakkari Üniversitesi, İBF, İktisat Bölümü

oktaykizilkaya@hakkari.edu.tr

Orcid No: 0000-0002-3412-5616

\section{İdris TURAN}

Arş. Gör., Sakarya Üniversitesi, SBF, Uluslararası İlişkiler Bölümü

turan.idris@gmail.com

Orcid No:0000-0002-8184-0110

Bu makaleye atıfta bulunmak için: Demez, S., Klzılkaya, O. \& Turan, I. (2021). "Türkiye'de İhracat, İthalat ve Ekonomik Büyüme Illişkisi: Zamanla Değişen Nedensellik Analizi”. Alanya Akademik Bakış, 5(2), Sayfa No.941-952.

\begin{tabular}{|c|c|}
\hline & ÖZET \\
\hline Anahtar kelimeler: & $\begin{array}{l}\text { Ithalat ve ihracat bir ekonominin büyüme oranlarının temel } \\
\text { belirleyicilerindendir. Bu nedenle bu konu hakkında literatürde ilişkinin }\end{array}$ \\
\hline İhracat, Ithalat, & varlığını ortaya koyan birçok teorik ve ampirik çalışma yer almaktadır. Fakat \\
\hline Büyüme, Zamanla & ilişkinin yönü konusunda bir fikir birliği söz konusu değildir. Bu çalışmada \\
\hline Değişen Nedensellik & Türkiye'de ihracat, ithalat ve ekonomik büyüme ilişkisi 1998Ç2-2017Ç4 \\
\hline & $\begin{array}{l}\text { dönemi çeyreklik veriler kullanılarak araştırılmıştır. Değişkenler arasındaki } \\
\text { ilişki Hacker ve Hatemi-J (2012) bootstrap nedensellik analizi ve değişkenler }\end{array}$ \\
\hline Makale Geliş & $\begin{array}{l}\text { arasındaki ilişkinin zamana bağlı olarak değişeceği varsayımı altında } \\
\text { zamanla değişen nedensellik analizi ile incelenmiştir. }\end{array}$ \\
\hline
\end{tabular}

Kabul Tarihi:

19.04.2021

Keywords:

Export, Import,

Economic Growth,

Time-Varying

Causality Test

\begin{abstract}
Import and export are the main determinants of the growth rates of an economy. For this reason, there are many theoretical and empirical studies about the existence of the relationship in this literature. But there is no consensus on the direction of the relation. In this study, the relationship between exports, imports and economic growth is investigated using quarterly data from the period 1971-2014 in Turkey. The relationship between the variables is analyzed with the bootstrap causality test proposed by Hacker
\end{abstract}


and Hatemi-J (2012) and time-varying causality test under the assumption that the relationship between the variables changed over time.

\section{GİRIŞ}

Ülkelerin ekonomik büyüme seviyelerini belirleyen en önemli faktörler, üretim ve dış ticaret (ithalat, ihracat) oranlarıdır. Her ne kadar literatürde ihracat ve ithalatın büyüme ile ilişkili olduğu konusunda fikir birliğgi olsa da ilişkinin yönü bakımından farklı görüşler yer almaktadır. Birinci görüş ihracattan ekonomik büyümeye doğru bir nedenselliğin olduğudur. Bu görüş ihracata dayalı büyüme hipotezi (export-led-growth) olarak adlandırılır. Bu hipoteze göre ihracat, firmalara, dış rekabetten dolayı kapasite kullanım oranında artış, ölçek ekonomilerinden yararlanma, kaynak tahsisi ve yeni iş imkanlarının yaratılması gibi olanaklar sağlayarak çıktıda bir artışa neden olabilmektedir (Balassa, 1978: 181; Feder, 1983: 61-62; Marin, 1992: 679). İkinci görüş büyümeden ihracata doğru bir nedenselliğin olduğunu ileri sürmekte ve büyüme kaynaklı ihracat hipotezi (growth-led-export) olarak adlandırılmaktadır. $\mathrm{Bu}$ önerme teknolojik yenikler ve nitelikli işgücünün verimlilik artışına yol açarak ihracatı artıracağını ileri sürmektedir (Krueger, 1990: 109; Vernon, 1992: 205). Böylece ihracattaki artış neticesinde artan döviz daha fazla aramalı ithaline neden olmakta ve üretimi artırmaktadır (Awokuse, 2007: 390). Üçüncü görüş ithalata dayalı büyüme hipotezidir. Bu görüşün savunucuları özellikle gelişmekte olan ülkelerde ithalatın ihtiyaç duyulan aramalı teminini ve teknoloji transferini sağlayarak uzun dönemde büyümeyi artıracağını önermektedir (Lawrence ve Weinstein, 2001: 2). Ayrıca Bhagwati (1988), Helpman ve Krugman (1985), Kunst ve Marin (1989) ve Grossman ve Helpman (1991) çalışmalarında ihracat ile ekonomik büyüme arasında çift yönlü nedensellik ilişkisi olduğunu belirtmişlerdir. Yukarıda bahsedilen durumların tümü analize konu olan ülke ya da ülkelerin ekonomi politikasının belirlenmesinde büyük öneme sahiptir. Örneğin bir ekonomi için yapılan analiz neticesinde ihracattan büyümeye tek yönlü bir nedensellik ilişkisinin varlığı durumunda ihracata yönelik ekonomi politikasını uygulamaya koymak tutarlı bir tercih olacaktır.

II. Dünya Savaşı'ndan 1980'lere kadar Türkiye liberal ve ithal ikameci sanayileşme stratejisini benimsemiştir. Amaç uzun vadede sanayileşme ve döviz çıkışını engellemekti. Nitekim 1970 petrol krizinin de etkisi ile ithal ikameci strateji başarılı olamamıştır. 1970'lerin sonunda yaşanan döviz darboğazı ve enflasyonist baskı neticesinde 24 Ocak 1980 kararları alınmıştır. Bu kararlar ekonominin yapısında köklü değişimleri beraberinde getirmiştir. Böylece Türkiye ihracata yönelik sanayileşme stratejisini uygulamaya koymuştur. Bu sayede ihracat, devlet tarafından sağlanan teşviklerle önemli düzeyde bir artış göstermiştir (Olgun, 1979: 165-166). 1981 yılında ihracat bir önceki yıla göre \%62 artmıştır. Bu artış 2006 yılına kadar devam etmiş̧ir. Aynı dönem içerisinde ithalatta ihracata paralel olarak yükselen bir trend izlemiştir. Bunun nedeni elbette ki ihracata konu olan malların üretiminde girdi olarak kullanılan aramalı ithalatıdır. 1980 yılından günümüze 1994, 2001 ve 2008 yıllarında krizler yaşanmıştır. Her ne kadar bu dönemlerde ithalata konu olan aramalı ithalinde belirli azalmalar yaşansa da dönem bir bütün olarak değerlendirildiğinde artış gözlemlenmektedir. Ayrıca Türkiye 2005 yılında AB'ye uyum süreci çerçevesinde AB'nin üye olmayan ülkelere uyguladığı Serbet Ticaret Anlaşması ve Genelleştirilmiş Tercihler Sistemine geçmiştir. (Gerni, vd., 2008: 20-22). Tüm bu verilerin 1şığında Türkiye ekonomisi için ithalat, ihracat ve büyüme ilişkisini bir bütün olarak değerlendirmek oldukça güçtür. Çünkü dönem içerisinde birçok ekonomik kriz ve 
politika değişikliği meydana gelmiştir. Bu nedenle Türkiye ekonomisindeki bu değişkenler arasındaki ilişki belirli dönemler itibariyle incelenmeye alınmalıdır.

Nedensellik ilişkinin istikrarı oldukça ilgi çekicidir, çünkü özellikle büyümenin gerçek katalizörünün tanımlanmasında önemli politika etkilerine sahiptir. Örneğin, ihracata dayalı büyüme hipotezinin istikrarlı olduğu tespit edilirse, İhracattaki genişleme yoluyla ekonomik büyümeyi teşvik etmeyi amaçlayan politikalar oldukça etkilidir. Öte yandan, ihracata dayalı büyüme hipotezi istikrarsız ise, ihracatın, özellikle uzun dönemli ekonomik büyüme sağlamak için iyi bir büyüme katalizörü olamayacağı sonucuna varılabilir (Tang vd., 2015: 230).

Bu çalışma Türkiye'de ithalat, ihracat ve ekonomik büyüme ilişkisini araştırmak amacıyla yapılmıştır. Bu ilişki özellikle izlenen politika ve zamanla değişim göstermektedir. Bu sebeple değişkenler arasındaki nedensellik ilişkisi hem bütün olarak hem de zamanla değişen nedensellik analizi ile incelenmiştir. Tüm dönemleri içeren Hacker ve Hatemi-J (2012) bootstrap nedensellik analizine göre hiçbir değişken arasında nedensellik ilişkisi bulunamamıştır. Fakat zamanla değişen bootstrap nedensellik analizi belirli dönemlerde tüm değişkenler için nedensellik ilişkisi olduğunu ortaya koymaktadır.

\section{LITERATÜR}

Literatürde, ihracat, ithalat ve büyüme arasındaki ilişkiyi inceleyen birçok çalışma bulunmaktadır. Tablo 1'de literatürde ihracat, ithalat ve büyüme ilişkisini belirlemeye yönelik yapılan çalışmaların özeti; ele alınan dönem, kullanılan yöntemler ve elde edilen sonuçlar çerçevesinde verilmiştir.

Tablo 1. Literatür Özeti

\begin{tabular}{llll}
\hline Yazarlar & $\begin{array}{l}\text { Ülke- } \\
\text { Dönem }\end{array}$ & $\begin{array}{l}\text { Ekonometrik } \\
\text { Yöntem }\end{array}$ & Sonuç \\
\hline \hline Furuoka (2007) & Filipinler, & Johansen & Elde edilen zaman serisi ve panel \\
& Endonezya, & Eşbütünleşme, & veri analizi sonuçları ele alınan \\
& Malezya & Granger & ülkelerde milli gelir ile ihracat \\
& $1985-2002$ & Nedensellik, Panel & miktarı arasında anlamlı bir ilişki \\
& & Veri Analizi, & olmadığını göstermektedir. \\
& & Pedroni Panel & \\
& & Eşbütünleşme, & \\
& & & \\
& & & \\
& &
\end{tabular}

\begin{tabular}{|c|c|c|c|}
\hline Yaprakl1 (2007) & $\begin{array}{l}\text { Türkiye } \\
1970 \text { - } 2005\end{array}$ & $\begin{array}{l}\text { Johansen } \\
\text { Eşbütünleşme, } \\
\text { Granger } \\
\text { Nedensellik }\end{array}$ & $\begin{array}{l}\text { Toplam ihracat ve sanayi } \\
\text { ihracatından büyümeye doğru tek } \\
\text { yönlü nedensellik ilişkisi elde } \\
\text { edilirken, tarım ihracatı ve } \\
\text { madencilik ihracatı ile büyüme } \\
\text { arasında ise iki yönlü nedensellik } \\
\text { bulunduğu sonucuna ulaş1lmıştır. }\end{array}$ \\
\hline Gerni vd. (2008) & $\begin{array}{l}\text { Türkiye } \\
1980-2006 \\
1989-2007\end{array}$ & $\begin{array}{l}\text { Granger } \\
\text { Nedensellik }\end{array}$ & $\begin{array}{l}\text { Çalışma sonucunda Türkiye'de } \\
\text { ithalata dayalı büyümenin ve ithalata } \\
\text { dayalı ihracat süreçlerinin var olduğu } \\
\text { sonucuna ulaşılmıştır. }\end{array}$ \\
\hline
\end{tabular}




\begin{tabular}{|c|c|c|c|}
\hline Y1lmazer (2010) & $\begin{array}{l}\text { Türkiye } \\
1991 \text { - } 2007\end{array}$ & $\begin{array}{l}\text { Granger } \\
\text { Nedensellik }\end{array}$ & $\begin{array}{l}\text { Çalışmada ithalat ve ihracat ile } \\
\text { büyüme arasında çift yönlü } \\
\text { nedensellik elde edilirken, ithalattan } \\
\text { ihracata ise tek yönlü nedensellik } \\
\text { ilişkisi elde edilmiştir. }\end{array}$ \\
\hline Ağayev (2011) & $\begin{array}{l}12 \text { Geçiş } \\
\text { Ekonomisi } \\
1994-2008\end{array}$ & $\begin{array}{l}\text { Pedroni Panel } \\
\text { Eşbütünleşme, } \\
\text { Holtz-Eakin vd. } \\
\text { (1988) } \\
\text { Nedensellik, } \\
\text { Granger } \\
\text { Nedensellik }\end{array}$ & $\begin{array}{l}\text { Kısa ve uzun dönemde büyümeden } \\
\text { ihracata doğru nedensellik ilişkisi } \\
\text { elde edilmiştir. }\end{array}$ \\
\hline $\begin{array}{l}\text { Yildiz ve Berber } \\
\text { (2011) }\end{array}$ & $\begin{array}{l}\text { Türkiye } \\
1989 \text { - } 2007\end{array}$ & $\begin{array}{l}\text { Engle- Granger } \\
\text { Eşbütünleşme, } \\
\text { Johansen } \\
\text { Eşbütünleşme, } \\
\text { Granger } \\
\text { Nedensellik }\end{array}$ & $\begin{array}{l}\text { Çalışma sonucunda incelenen } \\
\text { dönemde ithalata dayalı büyümenin } \\
\text { var olduğu tespit edilmiştir. }\end{array}$ \\
\hline $\begin{array}{l}\text { Gül ve Kamac1 } \\
\text { (2012) }\end{array}$ & $\begin{array}{l}\text { Gelişmekte } \\
\text { Olan ve } \\
\text { Gelişmiş } \\
\text { Ülkeler } \\
1980-2010 \\
1993-2010\end{array}$ & $\begin{array}{l}\text { Pedroni } \\
\text { Eşbütünleşme, } \\
\text { Granger } \\
\text { Nedensellik }\end{array}$ & $\begin{array}{l}\text { Gelişmekte olan ve gelişmiş } \\
\text { ülkelerde, ithalat ve ihracattan } \\
\text { büyümeye doğru nedensellik ilişkisi } \\
\text { olduğu sonucuna ulaş1lmıştır. }\end{array}$ \\
\hline Sandalc1lar (2012) & $\begin{array}{l}\text { BRIC } \\
\text { Ülkeleri } \\
1996-2006\end{array}$ & $\begin{array}{l}\text { Pedroni Panel } \\
\text { Eşbütünleşme, } \\
\text { Johansen } \\
\text { Eşbütünleşme } \\
\text { Granger } \\
\text { Nedensellik }\end{array}$ & $\begin{array}{l}\text { Kısa ve uzun dönemde ihracattan } \\
\text { büyümeye doğru nedensellik ilişkisi } \\
\text { elde edilmiştir. }\end{array}$ \\
\hline $\begin{array}{l}\text { Pistoresi ve Rinaldi } \\
\text { (2012) }\end{array}$ & $\begin{array}{l}\text { İtalya } \\
1863 \text { - } 2004\end{array}$ & $\begin{array}{l}\text { Johansen } \\
\text { Eşbütünleşme, } \\
\text { Granger } \\
\text { Nedensellik }\end{array}$ & $\begin{array}{l}\text { 1863-1913 dönemi için büyümeden } \\
\text { ihracata, ithalattan büyümeye; 1951- } \\
2004 \text { dönemi için ise ihracattan } \\
\text { büyümeye, büyümeden ithalata ve } \\
\text { ithalat ile ihracat arasında çift yönlü } \\
\text { nedensellik ilişkisi elde edilmiştir. }\end{array}$ \\
\hline Lim ve Ho (2013) & $\begin{array}{l}\text { Malezya } \\
1970 \text { - 2008 } \\
\text { Tayland } \\
1953 \text { - 2008 } \\
\text { Filipinler } \\
1958 \text { - 2008 } \\
\text { Endonezya } \\
1962 \text { - 2008 } \\
\text { Singapur } \\
1965 \text { - 2008 }\end{array}$ & $\begin{array}{l}\text { Johansen } \\
\text { Eşbütünleşme, } \\
\text { Granger } \\
\text { Nedensellik, } \\
\text { Hiemstra ve Jones } \\
\text { (1995) Doğrusal } \\
\text { Olmayan } \\
\text { Nedensellik, Diks } \\
\text { ve Panchenko } \\
\text { Doğrusal Olmayan } \\
\text { Nedensellik }\end{array}$ & $\begin{array}{l}\text { Doğrusal olmayan nedensellik testi } \\
\text { sonuçları, ihracatın ve GSYH'nın } \\
\text { nedensel etkisinin Tayland ve } \\
\text { Filipinler için doğrusal olmayan bir } \\
\text { biçimde olduğunu göstermiştir. }\end{array}$ \\
\hline
\end{tabular}




\begin{tabular}{|c|c|c|c|}
\hline Koçyiğit vd. (2015) & $\begin{array}{l}\text { BRIC-T } \\
\text { Ülkeleri } \\
1993-2013\end{array}$ & $\begin{array}{l}\text { Frekans Alanı } \\
\text { Nedensellik }\end{array}$ & $\begin{array}{l}\text { Çalışma sonuçları Türkiye, Çin, } \\
\text { Brezilya ve Rusya'da ihracata dayalı } \\
\text { büyüme hipotezinin farklı zaman } \\
\text { aralıklarında geçerli olduğunu } \\
\text { göstermektedir. Ayrıca, Hindistan ve } \\
\text { Güney Afrika için ithalata dayalı } \\
\text { büyüme hipotezi geçerlidir. }\end{array}$ \\
\hline $\begin{array}{l}\text { Sağlam ve Egeli } \\
\text { (2015) }\end{array}$ & $\begin{array}{l}\text { Türkiye } \\
1999-2013\end{array}$ & $\begin{array}{l}\text { Johansen } \\
\text { Eşbütünleşme, } \\
\text { Granger } \\
\text { Nedensellik }\end{array}$ & $\begin{array}{l}\text { Kısa dönemde ihracat ile büyüme } \\
\text { arasında çift yönlü nedensellik, uzun } \\
\text { dönemde ihracattan büyümeye doğru } \\
\text { tek yönlü nedensellik olduğu } \\
\text { sonucuna varılmıştır. }\end{array}$ \\
\hline
\end{tabular}

\begin{tabular}{|c|c|c|c|}
\hline Tang vd. (2015) & $\begin{array}{l}\text { Hong Kong } \\
1973-2007 \\
\text { Güney Kore } \\
1960-2007 \\
\text { Singapur } \\
1966-2007 \\
\text { Tayvan } \\
1961-2007\end{array}$ & $\begin{array}{l}\text { Johansen } \\
\text { Eşbütünleşme, } \\
\text { Toda-Yamamoto } \\
\text { Nedensellik, } \\
\text { Rolling } \\
\text { Regresyona Dayalı } \\
\text { Nedensellik }\end{array}$ & $\begin{array}{l}\text { Sonuçlar dört ekonominin her } \\
\text { birinde ihracata dayalı büyüme } \\
\text { hipotezinin geçerliliğinin ilgili analiz } \\
\text { dönemleri boyunca sabit olmadığını } \\
\text { göstermektedir. }\end{array}$ \\
\hline $\begin{array}{l}\text { Gokmenoglu vd. } \\
\text { (2015) }\end{array}$ & $\begin{array}{l}\text { Kosta Rika } \\
1980-2013\end{array}$ & $\begin{array}{l}\text { Johansen } \\
\text { Eşbütünleşme, } \\
\text { Granger } \\
\text { Nedensellik }\end{array}$ & $\begin{array}{l}\text { Granger nedensellik analizi sonuçları } \\
\text { büyümeden ihracat artışına doğru tek } \\
\text { yönlü nedensellik olduğunu } \\
\text { göstermektedir. }\end{array}$ \\
\hline $\mathrm{Ea}(2016)$ & $\begin{array}{l}\text { Sahra Alt1 } \\
\text { Afrika } \\
\text { Ülkeleri } \\
1985-2014\end{array}$ & $\begin{array}{l}\text { Pedroni Panel } \\
\text { Eşbütünleşme, } \\
\text { FMOLS, DOLS }\end{array}$ & $\begin{array}{l}\text { Çalışma sonuçları, ihracatın büyüme } \\
\text { üzerinde pozitif bir etkisinin } \\
\text { olduğunu göstermektedir. }\end{array}$ \\
\hline $\begin{array}{l}\text { Konstantakopoulou } \\
\text { (2016) }\end{array}$ & $\begin{array}{l}\text { Güney Euro } \\
\text { Bölgesi } \\
\text { Ülkeleri } \\
1960 \text { - } 2014\end{array}$ & $\begin{array}{l}\text { ARDL } \\
\text { Eşbütünleşme, } \\
\text { Toda-Yamamoto } \\
\text { Nedensellik }\end{array}$ & $\begin{array}{l}\text { Sonuçlar, Portekiz, İspanya ve } \\
\text { Yunanistan'da ihracat ile büyüme } \\
\text { arasında pozitif ilişsinin } \\
\text { bulunduğunu göstermektedir. Ayrıca } \\
\text { İspanya ve Yunanistan'da çift yönlü } \\
\text { nedensellik, Portekiz'de ihracattan } \\
\text { büyümeye tek yönlü nedensellik elde } \\
\text { edilmişken İtalya için nedensellik } \\
\text { ilişkisi elde edilememiştir. }\end{array}$ \\
\hline
\end{tabular}

Konu ile ilgili literatür incelendiğinde ekonometrik yöntem olarak nedensellik analizlerinin kullanıldığı çalışmaların oldukça fazla olduğu görülmektedir. Tablo 1'den izlenebileceği gibi, Türkiye örneğinde ampirik çalışmalar incelendiğinde, ele alınan dönem ve kullanılan ekonometrik yöntem farklılıkları gibi nedenlerden dolayı elde edilen sonuçların genellikle çelişkili olduğu görülmektedir.

\section{EKONOMETRIKK YÖNTEM}

Granger (1969) nedensellik testi uygulanırken, $x$ ve y gibi iki değişken için eğer $x$ değişkenine ait bilgilerin modele eklenmesi $y$ değişkeninin öngörüsüne katkı sağlıyorsa, $x$ değişkeni $y$ 
değişkeninin nedeni olarak ifade edilmekte ve nedenselliğin yönü $x$ değişkeninden $y$ değişkenine doğru belirlenmektedir. Literatürde Granger nedenselliği temel alarak geliştirilen testlerin sayısı gün geçtikçe artmaktadır. Granger (1969) nedensellik testinde serilerin durağan halleri kullanılmaktadır. Toda ve Yamamoto (1995) tarafından geliştirilen test ise serilerin farklı bütünleşme derecelerinde analize izin vermektedir. Hacker ve Hatemi-J (2006) ise Toda ve Yamamoto (1995) prosedürünü izleyerek, kritik değerlerin belirlenmesinde bootstrap yaklaşımının kullanılmasını önermişlerdir.

Toda-Yamamoto prosedürü gecikmesi artırılmış VAR modeline dayanmaktadır. VAR $(p)$ modeli Denklem (1) ile yazılabilir;

$$
y_{t}=v+A_{1} y_{t-1}+\cdots+A_{p} y_{t-p}+\varepsilon_{t}
$$

Burada $y_{t}, v$ ve $\varepsilon_{t}$ n-boyutlu vektörler ve $A_{r}$ ise $r$ gecikme için parametrelerin bir $n \times n$ matrisidir. Toda ve Yamamoto (1995), bütünleşik değişkenler arasındaki nedenselliği test edebilmek için kullanılabilecek Denklem (2) ile verilen genelleştirilmiş VAR $(p+d)$ modelini önermiştir.

$$
y_{t}=\hat{v}+\hat{A}_{1} y_{t-1}+\cdots+\hat{A}_{p} y_{t-p}+\cdots+\hat{A}_{p+d} y_{t-p-d}+\hat{\varepsilon}_{t}
$$

Burada sürecin $p$ gecikme uzunluğunun bilindiği varsayılmakta, $d$ ise modelde kullanılan değişkenlerin maksimum bütünleşme derecelerini göstermektedir. Eğer $H_{0}$ hipotezi reddedilemez ise $y_{t}$ 'nin $k$. elemanı, $y_{t}$ 'nin $j$. elemanının Granger nedeni olmadığ 1 ifade edilir (Hacker ve Hatemi-J, 2006: 1491);

$$
H_{0}: \mathrm{r}=1, \ldots, \mathrm{p} \text { için } A_{r} \text { matrisindeki j. satır } k \text {. sütündaki eleman sıfıra eşittir }
$$

Toda-Yamamoto (1995) testinde $\chi^{2}$ dağılımına sahip modifiye edilmiş (MWALD) test istatistiğini kullanılmaktadır. Hacker ve Hatemi-J (2006) çalışmalarında bootstrap dağılımını temel alan MWALD testinin, asimptotik dağılımın kullanıldığı durumlardan daha küçük boyut bozulmalara sahip olduğunu göstermişlerdir. Hacker ve Hatemi-J (2006) testinde, gecikme uzunluğu tahmin edilen VAR modeli ile dişsal olarak belirlenmektedir. Hacker ve Hatemi-J (2012) tarafından geliştirilen bootstrap temelli nedensellik testinde ise gecikme uzunluğunun içsel olarak belirlendiği durumlar araştırılmıştır.

Literatürde yer alan bütün nedensellik testleri seçilen gecikme uzunluğuna dayanmakta ve bu seçilen gecikme uzunluğu da sonuçları etkileyebilmektedir. Hatemi-J (2003, 2008) uygun gecikme uzunluğu seçiminde Schwarz (1978) ile Hannan ve Quinn (1979) bilgi kriterlerinin birleştirilmesi ile elde edilen HJC bilgi kriterini önermişlerdir. HJC bilgi kriteri Denklem (3) ile verilen formül ile hesaplanmaktadır.

$$
H J C=\ln \left(\operatorname{det} \widehat{\Omega}_{j}\right)+j\left(\frac{n^{2} \ln T+2 n^{2} \ln (\ln T)}{2 T}\right), \quad j=0,1, \ldots, p
$$

Denklem (3)'de $\operatorname{det} \widehat{\Omega}_{j}$, VAR (j) modelindeki kalıntıların tahmin edilen maksimum olabilirlik varyans- kovaryans matrisinin determinantıdır. Değişkenlerin sayısı $n$ ile gösterilmekte, $T$ örnek büyüklüğünü $l n$ ise doğal logaritmayı ifade etmektedir (Hatemi-J ve Uddin, 2014: 377).

Granger nedenselliğin olmadığını ifade eden sıfır hipotezi $H_{0}: C \hat{\beta}=0$ şeklindedir. Sıfır hipotezinin geçerliliği Toda ve Yamamoto (1995) tarafindan önerilen modifiye edilmiş Wald (MWALD) test istatistiği kullanılarak sınanmaktadır. 


$$
M W A L D=(C \hat{\beta})^{\prime}\left[C\left(\left(Z^{\prime} Z\right)^{-1} \oplus S_{U}\right) C^{\prime}\right]^{-1}(C \hat{\beta})
$$

Burada $\oplus$ Kronecker çarpımı, ve $C$ ise $\operatorname{pxn}(1+n(p+d))$ boyutlu matristir. $\hat{\delta}_{U}$, kısıtsız VAR modelinden elde edilen kalıntılar olmak üzere varyans-kovaryans matrisi $S_{U}=\hat{\delta}_{U}^{\prime} \hat{\delta}_{U} / T$ şeklindedir. vec (column-stacking) opertör ve $0_{n \times n d}, n$ satırlı ve $n(d)$ sütunlu sıfir matrisini temsil etmek üzere $\beta=\operatorname{vec}\left(v, A_{1}, \ldots, A_{p}, 0_{n \times n d}\right)$ ve $\hat{\beta}=\operatorname{vec}(\widehat{D})$ olarak tanımlanabilir.

Ele alınan seriler arasındaki nedensellik ilişkisi ekonomik ve politik değişimlerin etkisi ile zamana bağlı olarak değişebilmektedir. Bu değişimin istikrarlılığı zamana bağlı nedensellik analizi ile incelenebilmektedir. Bu çalı̧̧mada Hatemi-J (2012) tarafından önerilen ve gecikme uzunluğunun içsel olarak belirlendiği nedensellik analizi ve zamanla değişen nedensellik analizi uygulanmıştır. Tang (2013) tarafından önerilen zamanla değişen nedensellik testinde öncelikle alt örneklem boyutu $(\mathrm{T})$ belirlenmektedir. Belirlenen alt örneklem boyutu uygulanacak testin geçerli olabileceği büyüklükte olmalıdır. Nedensellik testi, $T$ gözlemlerinin başlangıç alt örneği için tahmin edilir. Daha sonra ilk gözlem alt örneklemden silinir ve gözlemlerin sonuna yeni bir gözlem eklenir. Nedensellik testi yeni alt örneklem ile tekrarlanır. Alt örneklem boyutu zaman içinde sabittir ve bu prosedür son gözlem kullanılana kadar devam edecektir. Son olarak, Granger nedensellik testi için MWALD istatistiği serisi oluşturulmaktadır. Oluşturulan $\chi^{2}$ istatistikleri, \%10 kritik değerlerle normalleştirilir. Normalleştirilmiş istatistik değeri 1 değerinin üzerinde ise boş hipotez reddedilmektedir (Tang vd., 2015:231).

\section{VERİ SETİ}

Bu çalışmada, Türkiye'de ihracat, ithalat ve büyüme arasındaki nedensellik ilişkisi, 1998Ç22017 Ç4 dönemi verileri kullanılarak incelenmiştir. Çalışmada toplam ihracat ve toplam ithalatın GSYH içindeki payları ve büyümeyi temsilen reel GSYH (2010 sabit fiyatlarla) verileri kullanılmıştır. Reel GSYH serisi analize logaritmik olarak alınmıştır. Seriler üçer aylık zaman periyodu halinde alındığı için mevsimsel etkiler görülebilmektedir. $\mathrm{Bu}$ nedenle değişkenlerde mevsimsel etkilerin olup olmadığına TRAMO/SEATS yöntemi ile bakılmıştır. Değişkenlerde mevsimsel etki olduğundan yine aynı yöntem ile seriler mevsimsellikten arındırılmıştır. Veriler, T.C. Merkez Bankası EVDS sistemi, OECD ve Data Stream veri tabanlarından alınmıştır.

\section{BULGULAR}

İlk olarak nedensellik analizinde kullanılacak değişkenlerin maksimum bütünleşme derecelerini belirlememiz gerekmektedir. Değişkenlerin bütünleşik derecelerini belirlemek için Augmented Dickey-Fuller (ADF), Phillips-Perron (PP), Kwiatkowski vd. (KPSS) birim kök testleri uygulanmış ve sonuçlar Tablo 2'de verilmiştir.

Tablo 2. Birim Kök Testi Sonuçları

\begin{tabular}{cccc}
\hline Değişkenler & ADF & PP & KPSS \\
\hline \hline$x$ & $-2.486(4)$ & $-2.347[9]$ & $0.843[6]^{*}$ \\
$\Delta x$ & $-6.559(3)^{*}$ & $-11.118[15]^{*}$ & $0.180[17]$ \\
$m$ & $-2.453(1)$ & $-1.924[3]$ & $0.845[6]^{*}$ \\
\hline
\end{tabular}




\begin{tabular}{lccc}
\hline$\Delta m$ & $-5.771(2)^{*}$ & $-6.576[6]^{*}$ & $0.051[3]$ \\
$g d p$ & $-0.146(1)$ & $-0.153[2]$ & $1.205[6]^{*}$ \\
$\Delta g d p$ & $-10.713(0)^{*}$ & $-10.683[3]^{*}$ & $0.147[2]$
\end{tabular}

Not: *, ** ve *** sırasıyla; \%1, \%5 ve \%10 düzeyinde anlamlılığı göstermektedir. Parantez içindeki değer tekrarlamalı t-istatistiği kullanılarak belirlenmiş uygun gecikme uzunluklarını, köşeli parantez içindeki değer ise Bartlett-Kernel kullanılarak belirlenmiş bant genişliğini göstermektedir.

Tablo 2'den izlenebileceği gibi birim kök testi sonuçlarına göre, ele alınan serilerin durağan olmadıkları, birinci farkları alındığında durağan hale geldikleri tespit edilmiştir. Hacker ve Hatemi-J (2012) tarafindan önerilen bootstrap nedensellik testi sonuçları Tablo 3 'te verilmiştir.

Tablo 3. Hacker ve Hatemi-J (2012) Bootstrap Nedensellik Testi Sonuçları

\begin{tabular}{|c|c|c|c|c|c|}
\hline \multirow{2}{*}{ Model } & \multirow{2}{*}{ MWALD } & \multirow{2}{*}{$p$} & \multicolumn{3}{|c|}{ Kritik Değerler } \\
\hline & & & $1 \%$ & $5 \%$ & $10 \%$ \\
\hline$x \nrightarrow g d p$ & 1.279 & 1 & 7.841 & 4.134 & 2.806 \\
\hline$g d p \nrightarrow x$ & 0.038 & 1 & 7.805 & 4.147 & 2.815 \\
\hline$m \nrightarrow g d p$ & 0.229 & 1 & 7.196 & 4.069 & 2.754 \\
\hline$g d p \nrightarrow m$ & 0.025 & 1 & 7.230 & 4.085 & 2.854 \\
\hline$x \nrightarrow m$ & 1.099 & 1 & 7.083 & 4.014 & 2.866 \\
\hline$m \nrightarrow x$ & 0.899 & 1 & 7.238 & 4.063 & 2.870 \\
\hline
\end{tabular}

Not: Bootstrap kritik değerleri 10.000 döngüyle elde edilmiştir. Uygun gecikme uzunluğu HJC kriterine göre belirlenmiştir.

Tablodan görüldüğü üzere tüm değişkenler için MWALD test istatistiği bootstrap kritik değerlerinden küçük olduğu için değişkenler arasında nedensellik ilişkisinin bulunmadığını belirten boş hipotez reddedilememektedir. Bu nedenle değişkenler arasında nedensellik ilişkisi bulunamamıştır. Şekil 1'de ise zamanla değişen nedensellik testi sonuçları görülmektedir.

Tablo 3'te Hacker ve Hatemi-J (2012) bootstrap nedensellik analizinde değişkenler arasında nedensellik ilişkisi bulunamazken, Şekil 1 ile gösterilen zamanla değişen nedensellik analizlerinde tüm değişkenler arasında belirli dönemlerde nedensellik ilişkisine rastlanmıştır. ' 1 ' çizgisinin üzeri nedensellik ilişkisinin olduğunu gösterirken altı ise nedensellik ilişkisinin olmadığı anlamına gelmektedir. İthalat, ihracat ve büyüme arasındaki zamanla değişen nedensellik analizleri 2003, 2007, 2008, 2010, 2012 ve 2014 yılları arasında yoğunlaşmaktadır. $\mathrm{Bu}$ nedensellik ilişkilerinin kriz dönemi sonrası toparlanma, siyasi istikrar ile ekonomideki olumlu beklentiler ve konjonktürel etkilerden kaynaklandığı düşünülmektedir. 


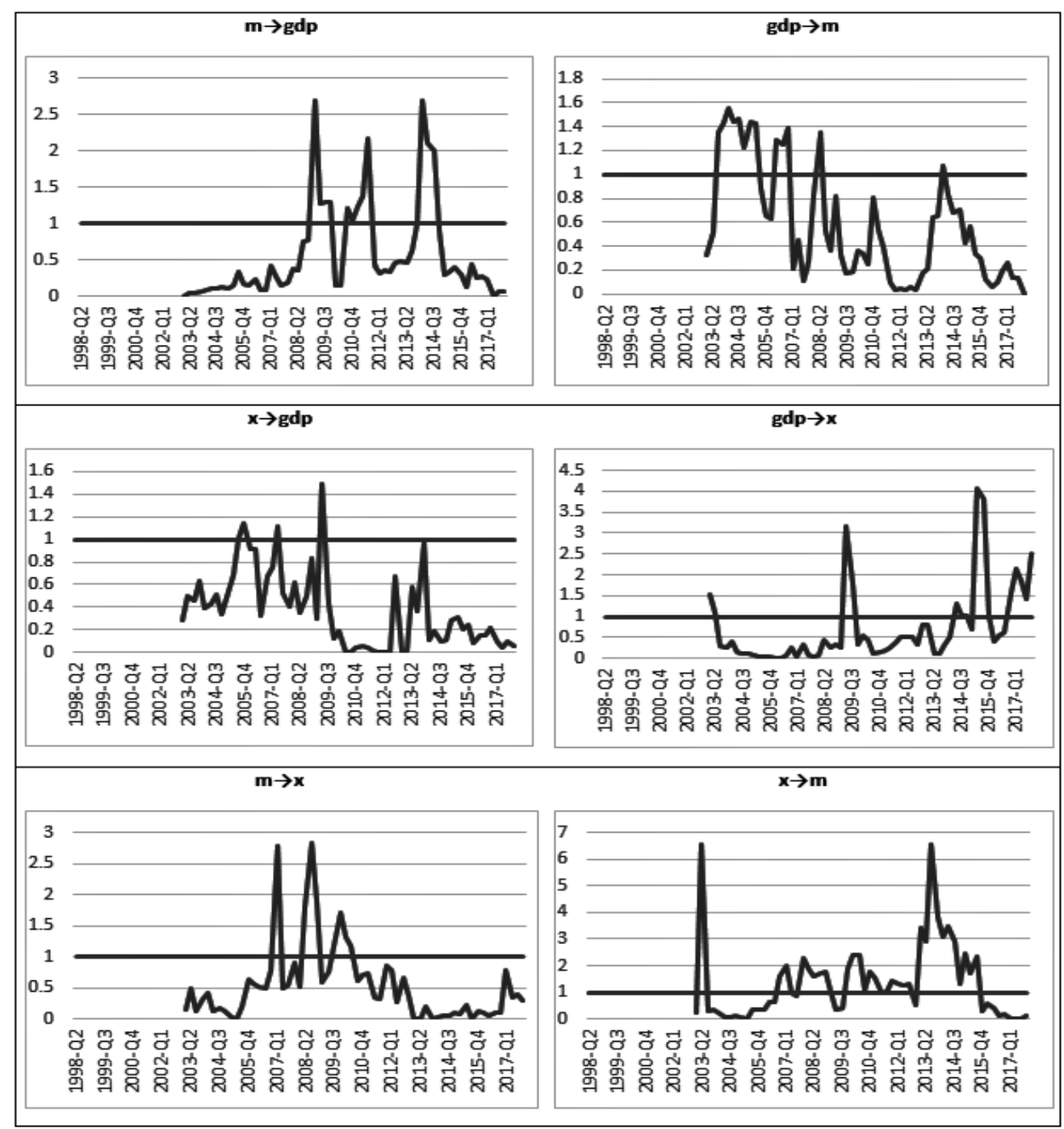

Şekil 1. Zamanla Değişen Nedensellik Testi Sonuçları

\section{SONUÇ}

Türkiye'nin son dönemlerde ihracata dayalı büyüme stratejisinin ve devlet tarafından sağlanan desteklerin etkisi ile ihracatını büyük oranda artırmıştır. Fakat bu artışa karşılık dış ticaret açığında da artış görülmektedir. Elbette ki bunun en büyün nedeni ham madde ve aramalı girdilerinin ithal edilmesidir. Ayrıca 1994, 2001 ve 2008 yıllarında yaşanan krizler ve AB'ye uyum sürecinde uygulamaya konulan bazı ortak gümrük tarifeleri Türkiye ekonomisinde ithalat, ihracat ve büyüme arasındaki ilişkiyi belirlemede anlamlı sonuçlar veremeyecektir. Bu çalışmada ihracat, ithalat ve büyüme arasındaki ilişki Hacker ve Hatemi-J (2012) bootstrap nedensellik analizi ve zamanla değişen bootstrap nedensellik analizi ile incelenmiştir. Hacker 
ve Hatemi-J (2012) nedensellik analizinde değişkenler arasında bir nedensellik ilişkisi bulunamazken zamanla değişen nedensellik analizinde tüm değişkenler arasında belirli dönemlerde nedensellik ilişkisinin olduğu sonucuna varılmıştır. Bu durum değişkenler arasındaki nedensellik ilişkisinin zamana bağlı olarak değişebileceği varsayımını ortaya koymaktadır. Zamanla değişen nedensellik testi, Türkiye için ihracata dayalı büyüme ve ithalata dayalı büyüme hipotezleri için nedensellik çıkarımlarının zaman içinde istikrarsız olduğunu göstermektedir. Yani, tam örneğe dayanan nedensellik testi sonucu iyi bir rehber değildir. Ayrıca zamanla değişen nedensellik testi sonuçlarına göre Türkiye için ihracata dayalı büyüme hipotezinin geçerliliği $\% 93$ sıklıkta; ithalata dayalı büyüme hipotezinin geçerliliği ise \%78 sıklıkta reddedilmektedir. Bu sonuçların 1şığında ithalata dayalı büyüme stratejisi ihracata yönelik stratejiden küçük bir farkla öndedir. Fakat bu fark politika seçimini belirleyecek düzeyde değildir. Sonuç olarak Türkiye'de ihracata ve ithalata dayalı büyüme stratejilerinin ele alınan dönem itibariyle etkin olmadığı görülmektedir. Bu durumun Türkiye'deki ihracatın ithalata bağlı olması ve ihraç edilen mal ve hizmetlerin yüksek katma değere sahip olmamasından kaynaklandığı düşünülmektedir. Bu nedenle ihraç mallarında yüksek kalite ve markalaşma toplam ihracat gelirlerini arttırarak hammadde ithalatından kaynaklı kayıpları en aza indirebilecektir. Ayrıca uzun vade hammaddesi yurtiçinde temin edilebilen ürünlerin üretim ve ihracatı teşvik edilmelidir.

\section{KAYNAKÇA}

AĞAYEV, S. (2011). “İhracat ve Ekonomik Büyüme İlişkisi: 12 Geçiş Ekonomisi Örneğinde Panel Eştümleşme ve Panel Nedensellik Analizleri’”. Ege Akademik Bakış, Cilt. 11, No. 2: 241-254.

AWOKUSE, T. O. (2007). "Causality between Exports, Imports, and Economic Growth: Evidence from Transition Economies”. Economics Letters, Cilt. 94, No. 3: 389-395.

BALASSA, B. (1978). "Exports and Economic Growth: Further Evidence". Journal of Development Economics, Cilt. 5, No. 2: 181-189.

BHAGWATI, J. N. (1988). "Export-Promoting Trade Strategy: Issues and Evidence". The World Bank Research Observer, 27-57.

EE, C. Y. (2016). "Export-led Growth Hypothesis: Empirical Evidence from Selected SubSaharan African Countries". Procedia Economics and Finance, Cilt. 35: 232-240.

FEDER, G. (1983). "On Exports and Economic Growth". Journal of Development Economics, Cilt. 12, No.1-2: 59-73.

FURUOKA, F. (2007). "Econometric Analysis of the Export-led Growth Hypothesis: Evidence for BIMP-EAGA Countries”. Philippine Journal of Development, Cilt. 34, No. 2: 2542.

GERNI, C., EMSEN, Ö. SELÇUK, D. M. K. (2008). "İthalata Dayalı İhracat ve Ekonomik Büyüme: 1980-2006 Türkiye Deneyimi”. Dokuz Eylül Üniversitesi, Cilt. 2: 20-22.

GÖKMENOĞLU, K. K. SEHNAZ, Z. TASPINAR, N. (2015). "The Export-led Growth: A Case Study of Costa Rica". Procedia Economics and Finance, Cilt. 25: 471-477. 
GRANGER, C. WJ. (1969). "Investigating Causal Relations by Econometric Models and Cross-Spectral Methods". Econometrica: Journal of the Econometric Society: 424438.

GROSSMAN, G. M. HELPMAN, E. (1991). "Trade, Knowledge Spillovers, and Growth". European Economic Review, Cilt. 35, No. 2-3: 517-526.

GÜL, E. KAMACI, A. (2012). "Dış Ticaretin Büyüme Üzerine Etkileri: Bir Panel Veri Analizi”. Journal of Alanya Faculty of Business/Alanya İşletme Fakültesi Dergisi, Cilt. 4 , No. 3.

HACKER, R. S. HATEMI-J, A. (2006). "Tests for Causality between Integrated Variables Using Asymptotic and Bootstrap Distributions: Theory and Application”. Applied Economics, Cilt. 38, No. 13: 1489-1500.

HACKER, R. S. HATEMI-J, A. (2012). “A Bootstrap Test for Causality with Endogenous Lag Length Choice: Theory and Application in Finance". Journal of Economic Studies, Cilt. 39, No. 2: 144-160.

HATEMI-J, A. (2003). “A New Method to Choose Optimal Lag Order in Stable and Unstable VAR Models". Applied Economics Letters, Cilt. 10, No. 3: 135-137.

HATEMI-J, A. (2008). "Tests for Cointegration with Two Unknown Regime Shifts with an Application to Financial Market Integration". Empirical Economics, Cilt. 35, No. 3: 497-505.

HATEMI-J, A. (2012). “Asymmetric Causality Tests with an Application”. Empirical Economics, Cilt. 43, No. 1: 447-456.

KOÇYİĞIT, A. BAYAT, T. KAYHAN, S. ŞENTÜRK, M. (2015). "Short and Long Term Validity of Export-Led Growth Hypothesis in BRICS-T Countries: A Frequency Domain Causality Approach”. Journal of Asian Development Studies, Cilt. 3, No. 4: 117-129.

KONSTANTAKOPOULOU, I. (2016). "New Evidence on the Export-led-growth Hypothesis in the Southern Euro-zone Countries (1960-2014)". Economics Bulletin, Cilt. 36, No. 1: 429-439.

KRUEGER, A. O. (1990). “Asian Trade and Growth Lessons". The American Economic Review, Cilt. 80, No. 2: 108-112.

HELPMAN, E. KRUGMAN, P. R. (1985). Market Structure and Foreign Trade: Increasing Returns, Imperfect Competition, and the International Economy, MIT Press.

KUNST, R. M. MARIN, D. (1989). “On Exports and Productivity: A Causal Analysis”. The Review of Economics and Statistics: 699-703.

LAWRENCE, R. Z.; WEINSTEIN, D. E. (2001). "Trade and Growth: Import-led or Exportled? Evidence from Japan and Korea". Rethinking the East Asian Miracle: 379-408.

LIM, S. Y. H., CHONG, M. (2013). "Nonlinearity in ASEAN-5 Export-led Growth Model: Empirical Evidence from Nonparametric Approach". Economic Modelling, Cilt. 32: 136-145. 
MARIN, D. (1992). "Is the Export-led Growth Hypothesis Valid for Industrialized Countries?". The Review of Economics and Statistics: 678-688.

PISTORESI, B. RINALDI, A. (2012). "Exports, Imports and Growth: New Evidence on Italy: 1863-2004”. Explorations in Economic History, Cilt. 49, No. 2: 241-254.

SABOGAL, J. S. HATEMI-J, A. CAYÓN-FALLON, E. (2016). "A Test of the Efficient Market Hypothesis with Regard to the Exchange Rates and the Yield to Maturity in Colombia”. WSEAS Transactions on Business and Economics, Cilt. 13: 321-329.

SAĞLAM, Y. EGELİ, H. A. (2015). “İhracata Dayalı Büyüme Hipotezi: Türkiye Örneği”. Dokuz Eylül Üniversitesi Sosyal Bilimler Enstitüsü Dergisi, Cilt. 17, No. 4: 517-530.

SANDALCILAR, A. R. (2012). "BRIC Ülkelerinde Ekonomik Büyüme ve İhracat Arasındaki İlişki: Panel Eşbütünleşme ve Panel Nedensellik”. Süleyman Demirel Üniversitesi İktisadi ve İdari Bilimler Fakültesi Dergisi, Cilt. 17, No. 1.

TANG, C. F. (2013). "A Revisitation of the Export-led Growth Hypothesis in Malaysia Using the Leveraged Bootstrap Simulation and Rolling Causality Techniques". Journal of Applied Statistics, Cilt. 40, No. 11: 2332-2340.

TANG, C. F. LAI, Y. W. ÖZTURK, İ. (2015). "How Stable is the Export-led Growth Hypothesis? Evidence from Asia's Four Little Dragons". Economic Modelling, Cilt. 44: 229-235.

VERNON, R. (1992). "International Investment and International Trade in the Product Cycle". In International Economic Policies and Their Theoretical Foundations (Second Edition): 415-435.

YAPRAKLI, S. (2007). "İhracat ile Ekonomik Büyüme Arasındaki Nedensellik: Türkiye Üzerine Ekonometrik Bir Analiz". Middle East Technical University Studies in Development, Cilt. 34, No. 1.

YILDIZ, E. B.; BERBER, M. (2011). “İthalata Dayalı Büyüme: 1989-2007 Türkiye Örneği”. Atatürk Üniversitesi İktisadi ve İdari Bilimler Dergisi, Cilt. 25.

YILMAZER, M. (2010). "Doğrudan Yabancı Yatırımlar, Dış Ticaret ve Ekonomik Büyüme İlişkisi: Türkiye Üzerine Bir Deneme”. Celal Bayar Üniversitesi SBE, Sosyal Bilimler Dergisi, Cilt. 8, No. 1: 241-260.

YILANCI, V. BOZOKLU, Ş. (2014). "Türk Sermaye Piyasasında Fiyat ve İşlem Hacmi İlişkisi: Zamanla Değişen Asimetrik Nedensellik Analizi”. Ege Academic Review, Cilt. 14, No. 2. 